\title{
Blog-Based Self-Understanding to Increase Self-Efficacy of Vocational High School Students
}

\author{
Indra Lacksana, M. Zuhdi Zainul Majdi, Sulma Mafirja \\ Universitas Negeri Semarang Indonesia \\ indralacksana@gmail.com
}

Submitted: 2020-03-15, Revised: 2020-04-13, Accepted: 2020-05-20

\begin{abstract}
Self-efficacy has an important role related to students' self-understanding. Lack of student selfunderstanding can result in students committing crimes, so it is essential to recognize and understand the potential of the student's self. This study aims to produce an innovation related to the media in guidance and counseling using blog-based self-understanding media to improve student self-efficacy. This research uses the Borg and Gall method, which has been simplified into five stages by the Puslitjaknov Team, but this research is limited to small scale tests. Pre-experimental research design: one-group pretest-posttest design using purposive random sampling involving ten students. Research findings show that blog-based self-understanding is useful for increasing student self-efficacy.
\end{abstract}

Keywords: Media Blog; Self-Understanding; Self-Efficacy

\section{Introduction}

Self-understanding is very necessary for adolescents, and it is essential to be able to make individuals better recognize the potential they have. Self-understanding is the cognitive description of adolescents about themselves, the basis and content of adolescent self-concepts. According to Piaget, at the age of 11-18 years old, entering the formal operational stage with the main characteristics of development is that children can think abstractly and logically, of course, by using thinking or thinking patterns (AM, 2015; Barrouillet, 2015; Ibda, 2015). This is confirmed by research that says a high school student's self-understanding is an in-depth recognition of her potentials that includes the realm of interests, abilities, personalities, values , and attitudes which the student's introduction of his personality (Rahmandani, Nurtjahyanti, \& Desiningrum, 2017). Without an understanding of themselves, adolescents will consistently experience instability in themselves, painful to adjust, inconsistent, nervous, and painful to protect themselves (Schuetz \& Multon, 2017).

Problems that occur at this time when adolescents do not have or even mistakenly in search of identity, one of which is drug abuse among children to adulthood. Based on data obtained from the National Narcotics Agency, around 27.32 percent of drug users in Indonesia are from students. Of course, the number is likely to increase again due to the circulation of several new types of narcotics (Amanda, 2017).

Students' self-understanding is essential because teenagers must regulate themselves to develop their potential. One factor that affects self-understanding is self-efficacy (Kim, 2018). Self-efficacy is one of the most influential aspects of self-knowledge in everyday human life (Fransiska, Asrori, \& Lestar, 2016), meaning that by recognizing and understanding their potential, the teenager can have the ability to succeed in doing something. Self-efficacy refers to an individual's trust in their capacity to manage action and also to engage in the efforts needed to achieve predetermined goals (Kwak, 2018). Other studies also reveal students who have self-understanding using intrinsic motivation are in harmony with high self-efficacy, which means self-understanding is directly related to self-efficacy where individuals who have high self-understanding then self-efficacy is also high and vice versa (Jo, Joung, Choi, \& Kim, 2018). 
Based on preliminary observations from several vocational schools in the Gresik region such as Sampean Vocational School, Cerme 1 Vocational School, Gresik Vocational School, related to self-efficacy with students' self-understanding showing problems arising because BK teachers in providing information services related to self-understanding followed by too slow self-efficacy This means that the giving of the material must start when students enter the Vocational School, not given incidentally when they need it or when an unwanted event occurs. Also, the teacher only explained that good and lousy self-understanding and the effect of selfefficacy were very lacking in reference material, and lack of media use was also an obstacle.

Based on the results of interviews of students, explaining that they feel bored while doing the process of information services related to listening to the material delivered by BK teachers because just telling by mouth is not used or accompanied by the media, even though students admit BK teachers are not technologically illiterate. Students also explain the process of face to face in one week felt less. Based on the results of the questionnaire that was distributed told that $83 \%$ of students want quality material, and new media innovations related to various materials available in information services

The handling that has been done so far, when such a problem occurs is given individual or group counseling. Still, the delivery of individual or group counseling is very late, because it is better to prevent than to treat, meaning BK teachers can anticipate that the problem does not occur. BK teachers can use various media in delivering information services related to selfunderstanding to improve self-efficacy, starting from the use of notebooks that have powerpoints, using webpages that are based online or offline, android media, etc. Like the research conducted by (Kocakoyun and Bicen, 2017) Produced findings that the structure of the use of the application being developed was definite, the structure of application education was by the existing curriculum, and this was rich in material and perhaps one of the apps that students could use for communication. The results also show that mobile apps support education and increase motivation. And the research supports mobile apps to improve academic achievement.

In the world of education, especially in the field of guidance and counseling, the development of technology such as e-counseling has begun, although the event is still glimpsed a little by counselors in Indonesia (Lacksana \& Nuryono, 2016). Research from (Ganesh Jengathe, 2015) resulting in that the modern Android mobile application is one application that is easy to install and is more responsible and more useful for students in the field of education. Furthermore, research on career information services using ICT (Information and communication technologies) the purpose of the study is that ICT is used to help students improve their decision making, the results, and recommendations of the study are in providing services it would be better if using the latest media used as a means and adapted to students' developmental tasks (Syakir, Mahmud, \& Achmad, 2016).

Based on recommendations from research conducted (Syakir et al., 2016), this study focused on the development of the latest media suitable for use by BK teachers, effective and efficient use. It can achieve the goal of increasing student self-efficacy; the media used is an online media blog to deliver material about self-understanding.

\section{Methods}

This study uses a development model of Borg and Gall with ten stages (Borg \& Gall, 2007) And has been simplified by the Puslitjaknov Team (Research Center for Policy and Education Innovation) into five stages. This research procedure is by the steps contained in the Borg and Gall development model sequence which has been simplified into five stages by the Puslitjaknov Team, namely: 1) Conducting product analysis to be developed, 2) Developing the initial product, 3) Expert validation and revision, 4) Small-scale field trials and product 
revisions, 5) Large-scale field trials and final products. However, this research was only conducted in small scale trials.

The measuring instrument used in this study was the adoption of the General SelfEfficacy Scale (GSE) with a total of 10 items used to measure the level of student self-efficacy and meCUE (Modular Evaluation of Key Components of User Experience) taken one indicator with 15 items for to test media and self-understanding blog material. The media feasibility test (expert) self-understanding blog, conducted by one material expert and one learning media expert. As for the empirical test in this study, there were 10 grade $\mathrm{X}$ students who had low selfefficacy at their school.

The analysis used in this study uses the analysis available in Microsoft Excel on the meCUE instrument, which calculates the mean and standard deviation, which will later be integrated with the level of product feasibility aspects. While empirical testing uses preexperimental: one-group pretest-posttest design. In this design, the treatment in question is a self-understanding blogging media. The assessment analysis used is the product eligibility criteria used to find out whether the developed media is feasible or still needs revision, the eligibility criteria are as follows: $81 \%$ - 100\% (Very good, no need to be revised), $66 \%-80 \%$ (Good, does not need to be changed), 56\% - 65\% (Not good, needs to be revised), 0\% - 55\% (Not good, needs to be edited).

\section{Results and Discussion}

In this study, the results and discussion are divided into three: testing of counseling guidance material, testing of media or products, and empirical or small-scale testing. First, testing the media or self-understanding blog product, in this stage, the first is a data collection study, the researcher researches (a) factual conditions of private sector service provision, and (b) the state of self-efficacy of class X students. Data collection is done through a questionnaire, interviews, and observations in class. The scale given to students is the adoption of the General Self-Efficacy Scale (GSE). Based on the results of measurements with a self-efficacy scale of 62 students obtained 41 students categorized as low, 12 students classified as medium, and nine students classified as high. Interviews were conducted with productive teachers and students, as well as observations of the learning process that took place in class.

Retrieval of data related to blog-based self-understanding uses meCUE (Modular Evaluation of Key Components of User Experience) to test the media and self-understanding blog material obtained by $79 \%$ of students and counseling teachers wanting innovations on the development of counselling especially to overcome low self-efficacy. Interviews were conducted with productive teachers and students, as well as observations of the learning process that took place in class.

At the stage of media development, the aim is to obtain criticism and suggestions to improve the blog media that has been developed. The results obtained from material experts are $81.5 \%$ with conversions based on the rating scale of (Mustaji, 2005) explained that Very Good and did not need to be revised. Still, some suggestions for the development towards better is to reproduce the material, especially with references related to journals and books from outside.

The results obtained from the media test were $78.57 \%$ when compared to the product eligibility criteria according to (Mustaji, 2005) it is good and does not need to be revised. Still, the advice given by media experts from Educational Technology Lecturers, Surabaya State University, is to change the front view to make it more exciting and to add a column so that BK teachers can fill in their material by student development. Also, testing is done to practitioners to see whether practitioners can use 
For empirical tests, based on data from the GSE (General Self-Efficacy Scale) questionnaire students who experienced self-understanding with low levels of self-efficacy increased significantly, can be seen in table 1 .

\begin{tabular}{ccc}
\multicolumn{3}{c}{ Table 1. Empirical Test Results } \\
\hline Subject & Pre-test & Post-test \\
\hline A & 42,5 & 82,5 \\
B & 40 & 77,5 \\
C & 45 & 80 \\
D & 42,5 & 80 \\
E & 35 & 77,5 \\
F & 32,5 & 70 \\
G & 50 & 75 \\
H & 30 & 77,5 \\
I & 37,5 & 72,5 \\
J & 42,5 & 70 \\
\hline
\end{tabular}

Furthermore, the total empirical test results are small-scale product trials or empirical tests, before being given a treatment (media self-understanding blog) subjects do pre-tests to see how much self-efficacy they have, after being given the media, it was tested again whether this media was able to increase the students 'self-efficacy, and the results of the total increase in students' self-efficacy can be seen in Table 2.

Table 2. Total Empirical Test Results

\begin{tabular}{lcc}
\hline & Pre-test & Post-test \\
\hline Total & 397,5 & 762,5 \\
Average & 39,75 & 76,25 \\
Increase in Yield & \multicolumn{2}{c}{$\mathbf{3 6 , 5}$} \\
\hline
\end{tabular}

Based on table 2, the total empirical test results show that blog-based self-understanding is useful for increasing student self-efficacy. Someone who has high self-efficacy can effectively deal with specific events or situations. This is in line with the opinion of researchers who say high self-efficacy improves the way of solving problems and mix critical thinking (Woodcock, Hitches, \& Jones, 2019).

Blog-based self-understanding increases students' self-efficacy, by increasing individual self-understanding and expanding knowledge and having strategies to move forward and be able to anticipate obstacles that arise. This is in line with research that says the characteristics of students who have self-understanding are shown by broadening knowledge and maintaining motivation, have strategies for progress that they will make and can evaluate obstacles that may arise (Schnabel, Kelava, \& Van de Vijver, 2016).

This finding is relevant to other research on developing self-understanding blogging media in personal guidance for students. The result is a self-understanding blog media along with a guide to using effective blog media because it can get a lot of information to increase knowledge for individual self-improvement (Siswahyu Bhaskoro, 2016). Strengthened by Murdiyanto's research on the development of a blog-based media career information service to enhance student career exploration. The results showed that blog-based career information was a worthy service for students to use and was effective in increasing the career exploration of junior high students in Magelang City (Murdiyanto, Purwanta, \& Kamaruddin, 2018)

Thus the results of research conducted by researchers explain that the development of a blog-based self-understanding model that increases student self-efficacy is described to have 
effective results and can provide students with sufficient understanding in providing knowledge related to efforts in developing themselves towards more good.

The development of blog-based self-understanding is also focused on: First, testing media or self-understanding blog products, in this stage, the first step is to conduct a data collection study, researchers research (a) factual conditions of personal service delivery and (b) terms of self-efficacy class $\mathrm{X}$ students. Thus it is expected that students' abilities can develop effectively. From the results of the study, it can be concluded that the development of a blog-based self-understanding model is useful in improving students 'self-efficacy and can be used to assist teacher guidance and counseling in increasing students' self-efficacy, especially in SMK Gresik.

\section{Conclusions and Suggestions}

Based on the results of the study, it can be concluded that the development of a blogbased self-understanding model is effective in improving students 'self-efficacy and can be used to assist teacher guidance and counseling in improving students' self-efficacy, especially at SMK Gresik. This media development uses an online system with a blog as a medium to convey self-understanding information. The material developed is adapted to POPBK, needs assessment, and reference books such as youth counseling, general psychology, educational psychology, etc.

This research is expected to become a stepping stone by researchers to refine further the limitations of the study, namely the use of the development model of Borg and Gall with its ten stages and large-scale tests, develop better media blogs with guidebooks and added with better features of research existing, add self-understanding instruments to be able to know the level of students' self-understanding and develop blog-based information services to the stage of product dissemination and implementation.

\section{References}

AM, M. (2015). Pengembangan Kognitif Jean Piaget Dan Peningkatan Belajar Anak Diskalkulia (Studi Kasus Pada MI Pangeran Dipenogoro Surabaya). Jurnal Kependidikan Islam, 6(2), 118-143.

Amanda, G. (2017). BNN: 27 Persen Pengguna Narkoba Pelajar dan Mahasiswa.

Barrouillet, P. (2015). Theories of cognitive development: From Piaget to today. Developmental Review, 38, 1-12.

Borg, \& Gall, G. (2007). Educational Researc: An Introduction. New York: Allyn and Bacon Inc.

Fransiska, M., Asrori, \& Lestar, S. (2016). Pengaruh Layanan Informasi Pemahaman Diri Terhadap Efikasi Siswa Kelas XI SMAN 2 Sungai Raya. Jurnal Pendidikan Dan Pembelajaran, 5(10), 1-11.

Ganesh Jengathe, D. V. R. (2015). Use of Android in Education System. International Journal of Electrical and Electronics Research, 3(4), 133-137.

Ibda, F. (2015). Perkembangan Kognitif: Teori Jean Piaget. Jurnal Intelektualita, 3(1), 27-38.

Jo, K., Joung, Y. J., Choi, J., \& Kim, H. (2018). Development and Application of Questionnaire for Self-Understanding and Change Capacity Related to Science Education: Focus on the Recognition of Pre-Service Elementary Teachers. Journal of The Korean Association For Science Education, 38(6), 901-917.

Kim, N.-J. (2018). A Study on the Influence of the Self-understanding on Self-directed learning 
of Middle students: A Mediating Effect of the Future-Oriented Thinking. Journal of Digital Convergence, 16(4), 355-361.

Kocakoyun, S., \& Bicen, H. (2017). Development and evaluation of educational android application. Cypriot Journal of Educational Sciences, 12(2), 58-68.

Kwak, M. (2018). The Causal Relationships among Career Preparation Behavior, Career Uncertainty, Career Decision-making Self-Efficacy, self-concept clarity and Career Insight in University Students. Journal of Agricultural Education and Human Resource Development.

Lacksana, I., \& Nuryono, W. (2016). Pengembangan Catatan Kumulatif Melalui Media Web Server Untuk Siswa SMA. Jurnal Bimbingan Dan Konseling, 6(1).

Murdiyanto, A., Purwanta, E., \& Kamaruddin, K. (2018). Pengembangan Layanan Informasi Karier Berbasis Media Blog Untuk Meningkatkan Eksplorasi Karier Siswa di SMP Kota Magelang. JBKI (Jurnal Bimbingan Konseling Indonesia), 2(2), 40-46.

Mustaji. (2005). Pembelajaran Berbasis Kontruktivistik Penerapan Dalam Pembelajaran Berbasis Masalah. Surabaya: UNESA Press.

Rahmandani, A., Nurtjahyanti, H., \& Desiningrum, D. R. (2017). Integrating an Employability Framework to Improve Occupational Self-Efficacy among Trainees of Vocational Training Institutions. 1st International Conference on Intervention and Applied Psychology (ICIAP 2017). Atlantis Press.

Schnabel, D. B. L., Kelava, A., \& Van de Vijver, F. J. R. (2016). The effects of using collaborative assessment with students going abroad: Intercultural competence development, self-understanding, self-confidence, and stages of change. Journal of College Student Development, 57(1), 79-94.

Schuetz, S., \& Multon, K. D. (2017). The Relationship of Alexithymia, Interpersonal Problems and Self-Understanding to Psychological Distress in College Students. North American Journal of Psychology, 19(1).

Siswahyu Bhaskoro, B. (2016). Pengembangan Media Blog Pemahaman Diri Dalam Bimbingan Pribadi Untuk Siswa Kelas X SMK Dr. Soetomo Surabaya. Jurnal BK UNESA, 6(2).

Syakir, M., Mahmud, A., \& Achmad, A. (2016). The Model Of ICT-Based Career Information Services And Decision-Making Ability Of Learners. International Journal of Environmental and Science Education, 11(13), 5969-5979.

Woodcock, S., Hitches, E., \& Jones, G. (2019). It's not you, it's me: Teachers' self-efficacy and attributional beliefs towards students with specific learning difficulties. International Journal of Educational Research, 97, 107-118. 